\title{
Preferred co-localization of chromosome 8 and 21 in myeloid bone marrow cells detected by three dimensional molecular cytogenetics
}

\author{
MARINA MANVELYAN ${ }^{1,2}$, PHILIPP KEMPF $^{1}$, ANJA WEISE ${ }^{1}$, KRISTIN MRASEK $^{1}$, \\ ANITA HELLER $^{1}$, AMELIE LIER ${ }^{1}$, KLAUS HÖFFKEN ${ }^{3}$, HANS-JÖRG FRICKE ${ }^{3}$, \\ HERBERT G. SAYER ${ }^{3}$, THOMAS LIEHR ${ }^{1}$ and HASMIK MKRTCHYAN ${ }^{1}$
}

\begin{abstract}
${ }^{1}$ Jena University Hospital, Institute of Human Genetics and Anthropology, Jena; ${ }^{2}$ Department of Genetic and Laboratory of Cytogenetics, State University, Yerevan, Armenia; ${ }^{3}$ Jena University Hospital, Internal Medicine II, Jena, Germany
\end{abstract}

Received March 27, 2009; Accepted May 13, 2009

DOI: 10.3892/ijmm_00000237

\begin{abstract}
The impact of chromosome architecture in the formation of chromosome aberrations is a recent finding of interphase directed molecular cytogenetic studies. Also positive correlation of translocation frequencies and spatial proximity of chromosomes was described. Thus, disease specific chromosomal translocations could be due to tissue specific genomic organization. However, no three-dimensional interphase fluorescence in situ hybridization (FISH) studies for the nuclear architecture of bone marrow (BM) cells have previously been done. In this study, BM of three secondary acute myelogenous leukemia (AML) cases with trisomy 8 and otherwise normal karyotype were evaluated. Bone marrow cells of one AML and one ALL (acute lymphoblastic leukemia) case, peripheral blood lymphocytes and human sperm, all of them with normal karyotype, served as controls. Multicolor banding (MCB) probes for chromosomes 8 and 21 were applied in suspension-FISH (S-FISH). Interestingly, in myeloid bone marrow cells chromosomes 8 (di- and trisomic) and 21 tended to co-localize with their homologue chromosome(s), rather than to be separated. Thus, the co-localization of chromosomes 8 and 21 might promote a translocation providing a selective advantage of $\mathrm{t}(8 ; 21)$ cells in AML-M2. In summary, the concept that tissue specific spatial proximity of chromosomes leads to enhanced translocation frequencies was further supported.
\end{abstract}

\section{Introduction}

In the interphase nucleus, chromosomes are located in specific regions, which are called 'chromosome territories' (1-5). In this

Correspondence to: Dr Thomas Liehr, Institut für Humangenetik, Postfach, D-07740 Jena, Germany

E-mail: i8lith@mti.uni-jena.de

Key words: nuclear architecture, co-localization, myeloid bone marrow cells, chromosome 8 , chromosome 21 connection, chromosome size and gene density are discussed to have an impact on the nuclear position of chromosomes (6-10). Furthermore, non-random positioning in interphase nuclei is known to be of importance for genomic stability and formation of chromosome aberrations. Tissue specificity of chromosomal translocations could be due to tissue specific genome organization $(11,12)$ and a positive correlation between spatial proximity of chromosomes/genes in interphase nuclei and translocation frequencies was shown $(5,10-13)$. Threedimensional (3D) fluorescence in situ hybridization (FISH) analysis has became a major tool for studying the higher order chromatin organization in the cell nucleus (15-21).

Trisomy 8 , the most frequently occurring numerical chromosome aberration in acute myeloid leukemia (AML) and myelodysplastic syndromes (MDS), can be associated with other karyotypic abnormalities or occur as sole abnormality. A variety of hematological diseases are connected with trisomy 8 , indicating a non-specific role in leukemia pathogenesis (22-25). Little is known about the prognostic impact of trisomy 8 as the sole change in AML and MDS (26). However, another frequent cytogenetic abnormality involving chromosome 8 , the reciprocal translocation $\mathrm{t}(8 ; 21)$ usually correlates with AML-M2 (27-30).

Up to now no studies on the 3D nuclear architecture of bone marrow (BM) cells, neither normal nor malignant ones were done, even though, recently, comparable studies in thyroid cancer cells were undertaken (31). Here we studied the (relative) 3D position of chromosomes 8 and 21 in interphase nuclei to each other. BM cells derived from three secondary AML cases with free trisomy 8 and one ALL and AML case, each, with normal karyotype were studied in comparison to peripheral blood lymphocytes and human sperm. The well established approach of interphase chromosome-specific multicolor banding (ICS-MCB) (19) combined with suspension FISH (S-FISH) (17) was chosen for this study.

\section{Material and methods}

Interphase cells. In the present study interphase cells were used, prepared according to standard procedures for chromosome 
Table I. Overview on the 7 cases, studied material and karyotypes.

\begin{tabular}{|c|c|c|c|}
\hline Case number & Age (y) & Material & Karyotype after GTG or mMCB* \\
\hline 1 & 30 & bone marrow (sec. AML from MDS) & $46, X Y,+8[21] / 46, X Y[4]^{*}$ \\
\hline 2 & 83 & bone marrow (sec. AML from MDS) & $46, X Y,+8[24] / 46, X Y[3]^{*}$ \\
\hline 3 & 57 & $\begin{array}{l}\text { bone marrow (sec. AML from MDS; } \\
\text { in blast crisis) }\end{array}$ & $46, X Y,+8[13] / 46, X Y[1]^{*}$ \\
\hline 4 & 63 & $\begin{array}{l}\text { bone marrow (AML in remission since } \\
6 \text { years after diagnosis AML-M2) }\end{array}$ & $46, X X[20]$ \\
\hline 5 & 46 & bone marrow (ALL-patient) & 46,XY[20] \\
\hline 6 & 25 & $\begin{array}{l}\text { stimulated peripheral blood-lymphocytes } \\
\text { (healthy) }\end{array}$ & $46, X X[20]$ \\
\hline 7 & 30 & sperm sample (healthy) & na-donor 46,XY[20] \\
\hline
\end{tabular}

ALL, acute lymphocytic leukemia; sec AML, secondary acute myelogenous leukemia; MDS, myelodysplastic syndrome; na, not available; y, years.

Table II. Localization of the homologous chromosomes 8 and 21 in 15-66 studied interphase nuclei per case (see also Table III).

\begin{tabular}{|c|c|c|c|c|c|c|}
\hline \multirow{3}{*}{ Case number } & \multicolumn{6}{|c|}{ Cells with disomy 8} \\
\hline & \multicolumn{3}{|c|}{ Chromosome $8(\%)$} & \multicolumn{3}{|c|}{ Chromosome $21(\%)$} \\
\hline & $\mathrm{t}$ & $\mathrm{n}$ & o & $\mathrm{t}$ & $\mathrm{n}$ & o \\
\hline 1 & - & 100 & - & - & 66.7 & 33.3 \\
\hline 2 & 7.1 & 78.6 & 14.3 & 28.6 & 64.3 & 7.1 \\
\hline 3 & 6.6 & 66.7 & 26.7 & 27.3 & 63.6 & 9.1 \\
\hline 4 & 3.2 & 77.4 & 19.4 & 38.7 & 54.8 & 6.5 \\
\hline 5 & - & 83.3 & 16.7 & 30.0 & 70.0 & - \\
\hline 6 & 6.7 & 53.3 & 40.0 & 20.0 & 66.7 & 13.3 \\
\hline 7 & na & na & na & na & na & na \\
\hline
\end{tabular}

\begin{tabular}{|c|c|c|c|c|c|c|c|c|c|}
\hline \multirow{3}{*}{ Case number } & \multicolumn{9}{|c|}{ Cells with trisomy 8} \\
\hline & \multicolumn{6}{|c|}{ Chromosome $8(\%)$} & \multicolumn{3}{|c|}{ Chromosome $21(\%)$} \\
\hline & $\mathrm{t}$ & $\mathrm{n}$ & $\mathrm{t}-\mathrm{n}$ & o & o-n & $o-t$ & $\mathrm{t}$ & $\mathrm{n}$ & o \\
\hline 1 & 3.7 & 44.4 & 44.4 & - & 7.5 & - & 2.2 & 70.3 & 7.5 \\
\hline 2 & 2.6 & 26.3 & 55.3 & - & 5.3 & 10.5 & 33.3 & 48.2 & 18.5 \\
\hline 3 & - & 38.6 & 29.5 & - & 2.4 & 29.5 & 40.7 & 59.3 & - \\
\hline
\end{tabular}

-, no such nuclei found; n, near by each other; na, not available; $o$, on the opposite sides of the nucleus; $t$, close together.

harvesting $(32,33)$. Interphases were obtained from BM (cases 1-5), peripheral blood lymphocytes (case 6) or a human sperm sample (case 7). BM cells were obtained from patient material, which were residual from cytogenetic diagnostics; patients gave informed consent for further use of this material for research. Peripheral blood lymphocytes and human sperm sample were obtained from healthy volunteers. A summary of the corresponding material applied, the number of evaluated cells and the obtained results are given in Table I. All karyotypes were determined by standard GTG-banding.

\section{Molecular cytogenetics}

Multitude multicolor banding (mMCB). For cases 1-3 the integrity and presence of normal chromosomes without any cryptic rearrangements was proven by multitude multicolor banding (mMCB) (34). Fourteen to 27 metaphases were evaluated per case (see Table I).

Multicolor banding (MCB) and suspension FISH (S-FISH). Multicolor banding (MCB) probe sets for chromosomes 8 and $21(35,36)$ were applied in suspension-FISH $($ S-FISH) as previously reported $(17,20,21,37)$. Images of 3D-preserved interphase nuclei were captured on a Zeiss Axioplan microscope and analyzed by Cell-P (Olympus) software. The number of evaluated cells is given in Tables II and III.

Evaluation. For the 3D-evaluation, position and distance of homologous chromosomes were determined. The interphase 
Table III. Co-localization of chromosomes 8 and 21 in interphase nuclei.

\begin{tabular}{|c|c|c|c|c|c|c|c|}
\hline \multirow[b]{3}{*}{ Case no. } & \multicolumn{5}{|c|}{ Cells with disomy $8(\%)$} & \multirow[b]{3}{*}{$\begin{array}{c}\text { Absolute no. } \\
\text { of no. } 21 \\
\text { localized } \\
\text { with no. } 8\end{array}$} & \multirow[b]{3}{*}{$\begin{array}{c}\text { Overall } \\
\text { evaluated } \\
\text { no. } 21\end{array}$} \\
\hline & \multicolumn{2}{|c|}{ One no. 21 is near } & \multicolumn{3}{|c|}{ Two no. 21 'n'/'t' are near } & & \\
\hline & One chr. 8 & $\begin{array}{l}\text { Two chr. } 8 \\
\text { (in 'n' or 't') }\end{array}$ & One chr. 8 & $\begin{array}{l}\text { Two chr. } 8 \\
\text { (in 'n' or ' } t \text { ') }\end{array}$ & $\begin{array}{c}\text { Two no. } 21 \\
\text { separated } \\
\text { from two no. } 8\end{array}$ & & \\
\hline 1 & 100.0 & - & - & - & - & 3 & 3 \\
\hline 2 & 32.1 & 1.8 & 21.4 & 21.4 & 10.7 & 43 & 56 \\
\hline 3 & 18.2 & - & 9.1 & 9.1 & 63.6 & 8 & 22 \\
\hline 4 & 22.6 & 3.2 & 38.7 & 16.1 & 19.4 & 50 & 62 \\
\hline 5 & 20.0 & 1.7 & 30.0 & 6.7 & 41.6 & 35 & 60 \\
\hline 6 & 16.7 & 3.3 & 26.7 & 6.7 & 46.6 & 16 & 30 \\
\hline 7 & 26.7 & - & - & - & 73.3 & 9 & 15 \\
\hline
\end{tabular}

Cells with trisomy $8(\%)$

\begin{tabular}{|c|c|c|c|c|c|c|c|c|}
\hline \multirow[b]{2}{*}{ Case no. } & \multicolumn{2}{|c|}{ One no. 21 is near } & \multicolumn{3}{|c|}{ Two no. 21 'n'/'t' are near } & \multirow[b]{2}{*}{$\begin{array}{c}\text { Two no. } 21 \\
\text { separated } \\
\text { from three } \\
\text { no. } 8\end{array}$} & \multirow[b]{2}{*}{$\begin{array}{c}\text { Absolute no. } \\
\text { of no. } 21 \\
\text { localized } \\
\text { with no. } 8\end{array}$} & \multirow[b]{2}{*}{$\begin{array}{c}\text { Overall } \\
\text { evaluated } \\
\text { no. } 21\end{array}$} \\
\hline & One chr. 8 & $\begin{array}{l}\text { Two chr. } 8 \\
\text { (in 'n' or 't') }\end{array}$ & One chr. 8 & $\begin{array}{l}\text { Two chr. } 8 \\
\text { (in 'n' or 't') }\end{array}$ & $\begin{array}{l}\text { Three chr. } 8 \\
\text { (in 'n' or 't') }\end{array}$ & & & \\
\hline 1 & 33.3 & 27.8 & 11.1 & 3.7 & 14.8 & 9.3 & 49 & 54 \\
\hline 2 & 18.5 & 13.0 & 14.8 & 29.6 & 7.4 & 16.7 & 45 & 54 \\
\hline 3 & 5.5 & 24.1 & 18.5 & 22.2 & 3.7 & 26.0 & 40 & 54 \\
\hline
\end{tabular}

Abbreviations see Table II.

nucleus was divided into two spheres, i.e. periphery $(\mathrm{P})$ and center $(\mathrm{C}) ; 50 \%$ of the nucleus radius was defined as 'center'. Thus, analyzed chromosomes could be allocated either as $\mathrm{C}$ or P. Similar as described in (20) the relative positions of the studied chromosomes to each other were recorded as 'close together' (t), 'near by each other' (n) or 'on the opposite sides of the nucleus' (o) for two homologue chromosomes. In cells with three chromosomes 8 this nomenclature was combined to 'o-n', 'o-t' or ' $\mathrm{t}-\mathrm{n}$ ' - for examples see Fig. 1. As in this study the relative positions of chromosomes 8 and 21 to each other were studied, this leads to the possible combinations shown in Figs. 2 and 3.

Statistics. Statistical analysis was performed using Student's t-test, One Way ANOVA (Analysis of Variance) and HolmSidak method. Statistical significance was defined as $\mathrm{p}<0.05$.

\section{Results}

In all investigated cases (apart from case 7) standard GTGbanding was applied for initial determination of the karyotype present in the studied patients/ tissues. The mMCB applied additionally in the three studied cases with trisomy 8 did not reveal any cytogenetic changes.

In all investigated cases chromosome 8 is predominantly positioned in the periphery $(\mathrm{P})$ of interphase nuclei (Fig. 4); according to statistical tests this was a significant finding (One Way ANOVA and Holm-Sidak method: $F=8.045$; $\mathrm{p}<0.001)$. In cases with trisomy 8 the additional copy of chromosome 8 tended to be located in periphery rather than central (detailed data not shown, but visible in Fig. 4). Overall, the localization of chromosome 21 is in all seven studied cases was $\sim 50 \%$ in periphery and $50 \%$ central. In one case with trisomy 8 (case 1) and the studied ALL BM cells (case 5) a slight tendency of a more central localization was observed (Fig. 4). In the other five cases chromosome 21 was located more frequently in the periphery.

In general, in all analyzed cases (including interphase cells with disomy and trisomy 8 , excluding sperm sample), homologue chromosomes 8 are located primarily in close proximity, i.e. $\mathrm{t}, \mathrm{n}$ or $\mathrm{t}-\mathrm{n}$ (Table II). There is no significant difference between BM cells with normal and abnormal karyotype (One Way ANOVA: $F=1.690 ; p=0.112$ ). Comparing peripheral blood lymphocytes (case 6) with BM cells (cases 1-5) chromosome 8 had a higher co-localization rate in the latter. Additionally, in all the studied cases (apart from haploid sperm) homologue chromosomes 21 were situated near each other or close together in 66.7 to $100 \%$ of the studied cells.

In sperm (case 7), stimulated peripheral blood lymphocytes (i.e. T-lymphocytes, case 6) and in BM-cells from ALL (case 5) the co-localization rate of chromosomes 8 and 21 


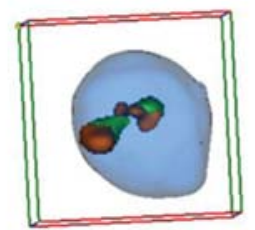

A

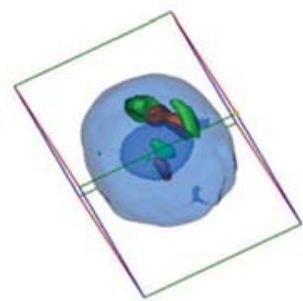

D

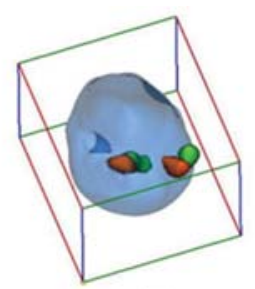

B

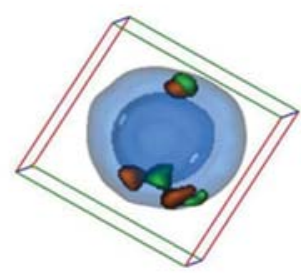

E

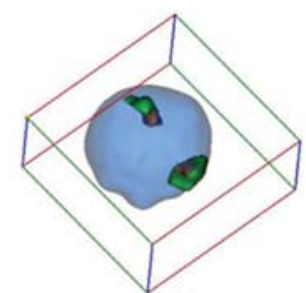

C

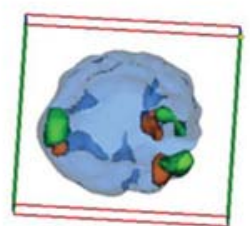

F

Figure 1. Modes of localization of homologue chromosomes 8 (brown and green pseudo-colors staining the short and the long arms, respectively) in bone marrow interphase cells (in blue, two shades are without any specific meaning) are depicted surrounded by edge lines of cubes as provided by the applied CELL-P software. Disomic cells: (A) close together (= t); (B) near each other (n); (C) on the opposite sides of the nucleus (= o). Trisomic cells: (D) t-n; (E) t$\mathrm{o} ;(\mathrm{F}) \mathrm{n}-\mathrm{o}$.
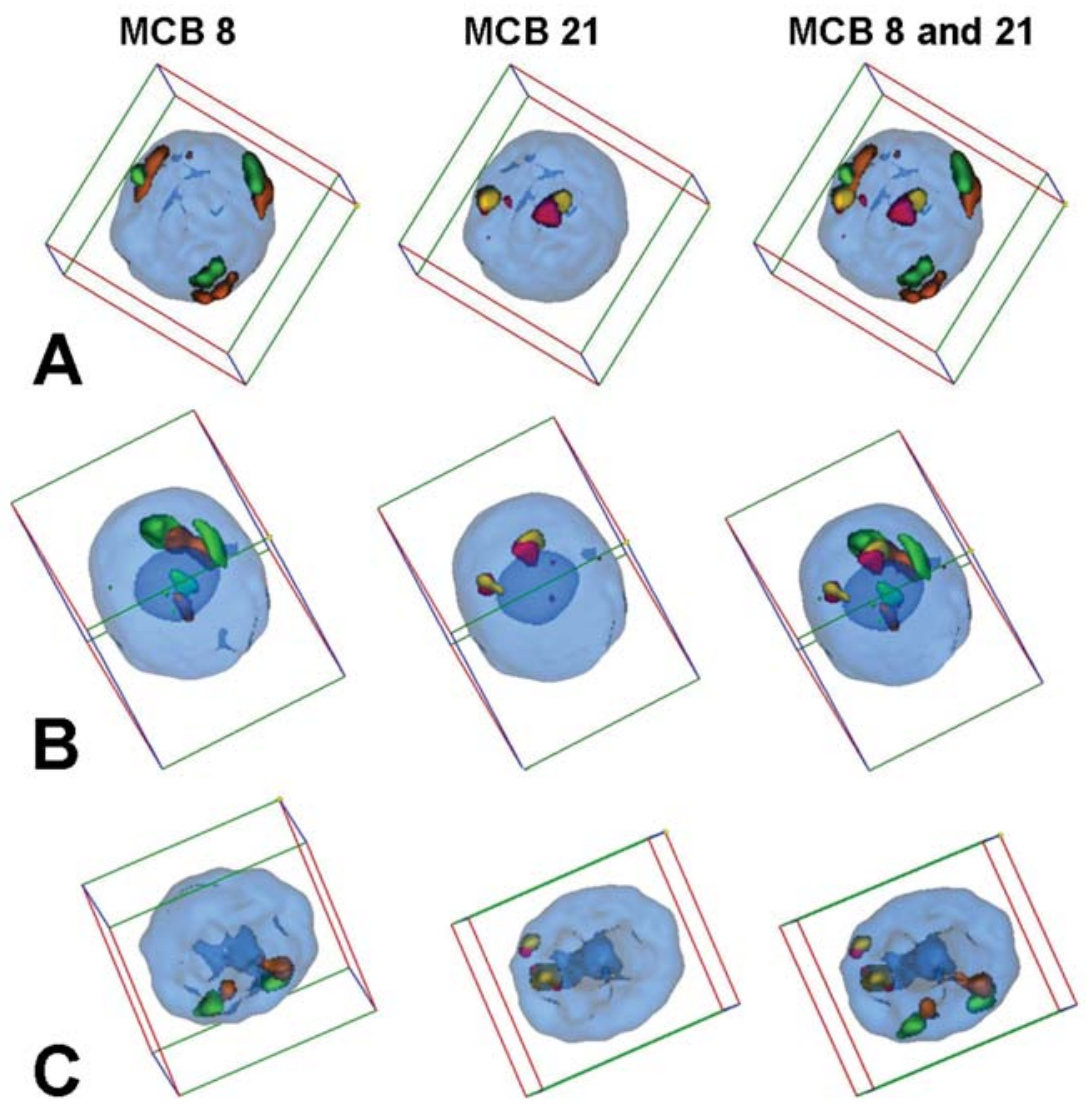

Figure 2. Examples of co-localization of chromosomes 8 (pseudo-colored as described in Fig. 1) and 21 (red and yellow pseudo-colors) in bone marrow derived interphase cells (depiction as in Fig. 1): (A) Three copies of chromosome 8 and two copies of chromosome 21; all homologous chromosomes are well separated. (B) Three copies of chromosome 8 and two copies of chromosome 21; both chromosome 21 are well separated with two chromosomes 8 , located in position ' $t$ '. (C) Two copies of chromosome 8 and 21, each; all chromosomes are well separated.

was as expected (Table IV). However, in all studied AMLcases, with exception of disomic cells of case 3 , a statistically significant difference between random and observed co- localization of chromosomes 8 and 21 was detected (t-test, case 1: $\mathrm{p}=0.005$ (disomy), $\mathrm{p}=0.002$ (trisomy); case $2: \mathrm{p}=0.006$ (disomy), $\mathrm{p}=0.002$ (trisomy); case $3 \mathrm{p}=<0.001$ (trisomy). Thus, 

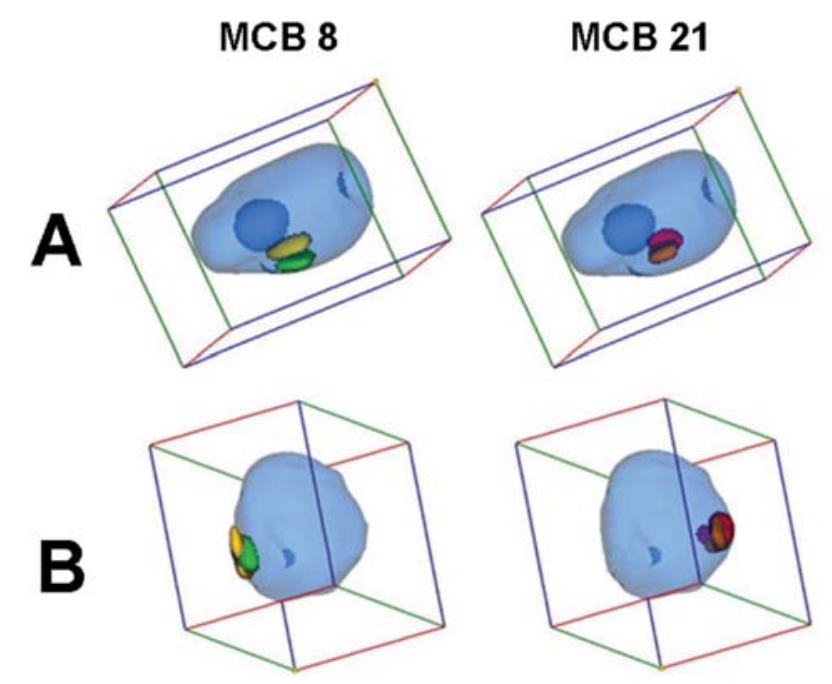

\section{MCB 8 and 21}
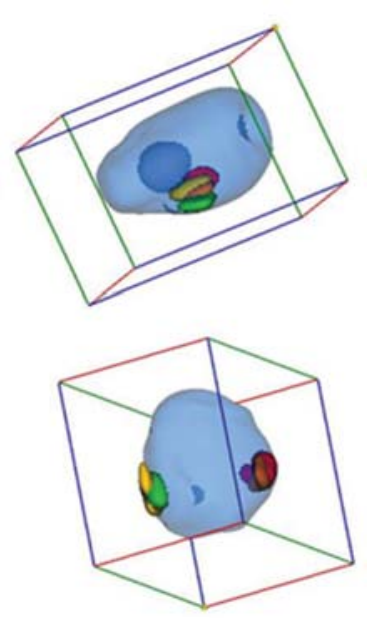

Figure 3. Examples of co-localization of chromosomes 8 and 21 in human sperm: in (A) chromosomes 8 and 21 are co-localized and in (B) they are well separated. Depiction as described in Fig. 2; yellow and green for chromosome 8 and orange, violet and pink pseudo-colors for chromosome 21 (orientation short to long arm).

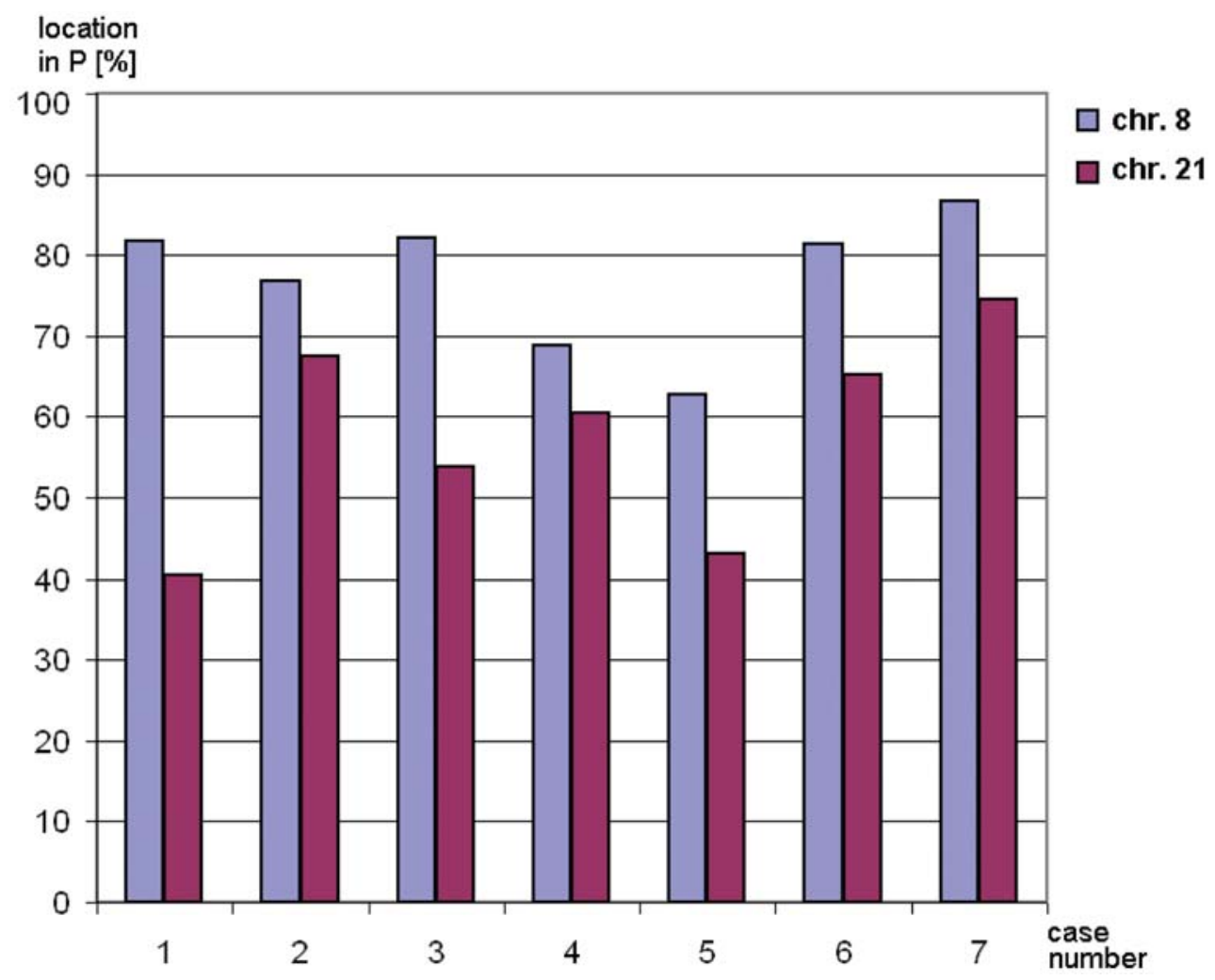

Figure 4. The percentage of chromosomes 8 (blue) and 21 (purple) detected in periphery of the interphase nuclei in the seven studied cases is depicted.

spatial proximity of chromosomes 8 and 21 is different in BM-cells of the myeloid line in interphase nuclei than in other cell types.

\section{Discussion}

Exclusion of cryptic rearrangements in the studied cases with trisomy 8 . The presence of further cryptic rearrangements in the three studied cases with trisomy 8 was excluded by mMCB.
This finding is in concordance with other previous studies, which, however, only were focused on chromosome $8(26,38)$. The usefulness of this approach was proven previously $(39,40)$.

Position of chromosomes 8 and 21 in interphase nuclei. Chromosome 8 is with statistic significance predominantly positioned in the periphery (P) of interphase nuclei (Fig. 4). The position of chromosome 8 in BM cells and peripheral 
Table IV. Comparison of observed with random colocalization of chromosomes 8 and 21 .

\begin{tabular}{lcc}
\hline Case no. & $\begin{array}{c}\text { Observed co- } \\
\text { localization }\end{array}$ & $\begin{array}{c}\text { Random co- } \\
\text { localization }\end{array}$ \\
\hline 1 (disom) & 100 & $43.2 \pm 0$ \\
1 (trisom) & $90.7 \pm 4.0$ & $67.3 \pm 6.4$ \\
2 (disom) & $89.3 \pm 5.7$ & $49.0 \pm 6.7$ \\
2 (trisom) & $83.3 \pm 5.1$ & $67.3 \pm 6.4$ \\
3 (disom) & $36.4 \pm 10.5$ & $49.0 \pm 10.9$ \\
3 (trisom) & $74.0 \pm 6.0$ & $67.3 \pm 6.4$ \\
4 (disom) & $80.6 \pm 5.1$ & $49.0 \pm 6.4$ \\
5 (disom) & $58.4 \pm 6.4$ & $49.0 \pm 6.5$ \\
6 (disom) & $53.4 \pm 9.2$ & $49.0 \pm 9.3$ \\
7 (monosom) & $26.7 \pm 11.8$ & $14.3 \pm 9.4$ \\
\hline
\end{tabular}

Values for random co-localization were as follows: it was established that one chromosome 8 and 21 , each, uncover $1 / 7$ of the nucleus. Thus, the random co-localization rate for a joint arrangement of both chromosomes can be calculated as: $\mathrm{Pn} \approx 1-(1-$ np)m. m, ploidy of chromosome 21 ; n, ploidy of chromosome 8; $\mathrm{p}, 1 / 7 ; \mathrm{Pn}$, random co-localization rate of chromosomes 8 and 21.

blood-lymphocytes is in concordance with the data of our previous study determined in haploid human sperm (21). The additional chromosome 8 was located in periphery rather than central. If this is general behavior when a trisomy is present cannot be answered yet. Observed position of chromosome 21 was in general in concordance with the literature $(20,21)$.

Orientation of homologue chromosomes to each other. Homologue chromosomes 8 are located primarily in close proximity. If there is really a higher rate of co-localization in blood lymphocytes (case 6) than in BM cells (cases 1-5) needs to be substantiated by further studies. In all here studied diploid cases (cases 1-6) homologue chromosomes 21 behaved as postulated for acrocentrics and co-localized to each other $(20,21)$.

Co-localization of chromosomes 8 and 21 in interphase nuclei. Correlation between spatial proximity of chromosomes/ genes in interphase nuclei and translocation frequencies was shown previously: chromosomes located in proximity undergo translocation events more frequently than distantly located ones $(11,13-14)$. To test this hypothesis for the reciprocal translocation $\mathrm{t}(8 ; 21)$ usually correlated with AML, here a 3D analysis for co-localization of chromosomes 8 and 21 was done (Table III and IV). A significant enhanced co-localization rate was found in all studied AML-cases, with exception of disomic cells of case 3 , compared to controls. Thus, spatial proximity of chromosomes 8 and 21 is different in BM-cells of the myeloid line in interphase nuclei than in other cell types. It is not clear why the disomic cells of case 3 showed different interphase architecture compared to the other AML-cases and even to the trisomic cells of the same case. However, this patient was studied during blast crisis (Table I), which might be connected to this phenomenon.
In conclusion, the results of this pilot study indicate the following: (A) in concordance with previous studies $(26,38)$, no further cytogenetic changes resolvable by FISH-banding techniques are present in cases with trisomy 8. (B) Even though in this study we could not distinguish malignant and non-malignant BM cells it is obvious, that chromosomes 8 and 21 are predominantly co-localized in myeloid BM cells compared to stimulated peripheral blood-lymphocytes, lymphoid BM-cells and sperm. (C) Among myeloid malignant $\mathrm{BM}$ cells there could possibly exist two groups, one with predominant co-localization of chromosomes 8 and 21 (cases 1, 2, 4 and 5), and one without that predominance (case 3). The latter observation could also be important in connection with the blast crisis present at the time of studying the corresponding patient. (D) Co-localization of chromosomes 8 and 21 might promote a translocation between these two chromosomes providing a selective advantage of $t(8 ; 21)$ cells in AML-M2, but not in other cell types.

Overall, further studies in BM cells are necessary for delineation of the tissue specificity of interphase architecture in this cell type as in cancer in general. At present even a clinical impact on malignancies of 3D-chromosome positioning can becomes more and more likely as supported by recent comparable findings in thyroid cancer (31).

\section{Acknowledgements}

Supported by the Stefan-Morsch-Stiftung, the DFG (LI 820/ 21-1) and the IZKF Jena. Also partly supported by DLR/ BMBF ARM 08/001, IZKF Jena (Start-up S16), IZKF together with TMWFK (TP 3.7 and B307-04004), University Jena, Evangelische Studienwerk e.V. Villigst, Stiftung Leukämie and DAAD (D/07/09624).

\section{References}

1. Cremer $\mathrm{T}$ and Cremer C: Chromosome territories, nuclear architecture and gene regulation in mammalian cells. Nat Rev Genet 2: 292-301, 2001.

2. Lemke J, Claussen J, Michel S, Chudoba I, Mühlig P, Westermann M, Sperling K, Rubtsov N, Grummt UW, Ullmann P, Kromeyer-Hauschild K, Liehr T and Claussen U: The DNAbased structure of human chromosome 5 in interphase. Am J Hum Genet 71: 1051-1059, 2002.

3. Weise A, Starke H, Heller A, Claussen U and Liehr T: Evidence for interphase DNA decondensation transverse to the chromosome axis: a multicolor banding analysis. Int J Mol Med 9: 359-361, 2002.

4. Williams RE and Fisher AG: Chromosomes, positions please! Nat Cell Biol 5: 388-390, 2003.

5. Branco MR and Pombo A: Intermingling of chromosome territories in interphase suggests role in translocations and transcription dependent associations. PLoS Biol 4: E138, 2006.

6. Croft JA, Bridger JM, Boyle S, Perry P, Teague P and Bickmore WA: Differences in the localization and morphology of chromosomes in the human nucleus. J Cell Biol 145: 119-131, 1999.

7. Sun HB, Shen J and Yokota H: Size-dependent positioning of human chromosomes in interphase nuclei. Biophys J 79: 184-190, 2000.

8. Tanabe H, Müller S, Neusser M, von Hase J, Calcagno E, Cremer M, Solovei I, Cremer C and Cremer T: Evolutionary conservation of chromosome territory arrangements in cell nuclei from higher primates. Proc Natl Acad Sci USA 99: 4424-4429, 2002.

9. Bolzer A, Kreth G, Solovei I, Koehler D, Saracoglu K, Fauth C, Müller S, Eils R, Cremer C, Speicher MR and Cremer T: Threedimensional maps of all chromosomes in human male fibroblast nuclei and prometaphase rosettes. PLoS Biol 3: E157, 2005. 
10. Grasser F, Neusser M, Fiegler H, Thormeyer T, Cremer M, Carter NP, Cremer T and Müller S: Replication-timingcorrelated spatial chromatin arrangements in cancer and in primate interphase nuclei. J Cell Sci 121: 1876-1886, 2008.

11. Meaburn KJ, Misteli T and Soutoglou E: Spatial genome organization in the formation of chromosomal translocations. Semin Cancer Biol 17: 80-90, 2007.

12. Brianna Caddle L, Grant JL, Szatkiewicz J, van Hase J, Shirley BJ, Bewersdorf J, Cremer C, Arneodo A, Khalil A and Mills KD: Chromosome neighborhood composition determines translocation outcomes after exposure to high-dose radiation in primary cells. Chromosome Res 15: 1061-1073, 2007.

13. Bickmore WA and Teague P: Influences of chromosome size, gene density and nuclear position on the frequency of constitutional translocations in the human population. Chromosome Res 10: 707-715, 2002

14. Roix JJ, McQueen PG, Munson PJ, Parada LA and Misteli T: Spatial proximity of translocation-prone gene loci in human lymphomas. Nat Genet 34: 287-291, 2003.

15. Cremer M, von Hase J, Volm T, Brero A, Kreth G, Walter J, Fischer C, Solovei I, Cremer C and Cremer T: Non-random radial higherorder chromatin arrangements in nuclei of diploid human cells. Chromosome Res 9: 541-567, 2001.

16. Solovei I, Cavallo A, Schermelleh L, Jaunin F, Scasselati C, Cmarko D, Cremer C, Fakan S and Cremer T: Spatial preservation of nuclear chromatin architecture during threedimensional fluorescence in situ hybridization (3D-FISH). Exp Cell Res 276: 10-23, 2002.

17. Steinhaeuser U, Starke H, Nietzel A, Lindenau J, Ullmann P, Claussen U and Liehr T: Suspension (S)-FISH, a new technique for interphase nuclei. J Histochem Cytochem 50: 1697-1698, 2002.

18. Verma RS and Babu A: Human chromosomes - Manual of basic techniques. New York, Pergamon Press, 1998.

19. Iourov IY, Liehr T, Vorsanova SG and Yurov YB: Interphase chromosome-specific multicolor banding (ICS-MCB): a new tool for analysis of interphase chromosomes in their integrity. Biomol Eng 24: 415-417, 2007.

20. Manvelyan M, Hunstig F, Mrasek K, Bhatt S, Pellestor F, Weise A and Liehr T: Position of chromosomes 18, 19,21 and 22 in 3D-preserved interphase nuclei of human and gorilla and white hand gibbon. Mol Cytogenet 1: 9, 2008.

21. Manvelyan M, Hunstig F, Bhatt S, Mrasek K, Pellestor F, Weise A, Simonyan I, Aroutiounian R and Liehr T: Chromosome distribution in human sperm - a 3D multicolor bandingstudy. Mol Cytogenet 1: 25, 2008.

22. Pedersen B: MDS and AML with trisomy 8 as the sole chromosome aberration show different sex ratios and prognostic profiles: a study of 115 published cases. Am J Hematol 56: 224-229, 1997

23. Cuneo A, Bigoni R, Roberti MG, Bardi A, Rigolin GM, Piva N, Mancini M, Nanni M, Alimena G, Mecucci C, Matteucci C, La Starza R, Bernasconi P, Cavigliano P, Genini E, Zaccaria A, Testoni N, Carboni C and Castoldi G: Detection and monitoring of trisomy 8 by fluorescence in situ hybridization in acute myeloid leukemia: a multicentric study. Haematologica 83: 21-26, 1998

24. Schoch C, Kohlmann A, Dugas M, Kern W, Schnittger S and Haferlach T: Impact of trisomy 8 on expression of genes located on chromosome 8 in different AML subgroups. Genes Chromosomes Cancer 45: 1164-1168, 2006.

25. Paulsson K and Johansson B: Trisomy 8 as the sole chromosomal aberration in acute myeloid leukemia and myelodysplastic syndromes. Pathol Biol (Paris) 55: 37-48, 2007.

26. Heller A, Brecevic L, Glaser M, Loncarevic I, Gebhart E, Claussen U and Liehr T: Trisomy 8 as the sole chromosomal aberration in myelocytic malignancies: a comprehensive molecular cytogenetic analysis reveals no cryptic aberrations. Cancer Genet Cytogenet 146: 81-83, 2003.
27. Kratz CP, Antonietti L, Shannon KM, Dole MG and Friebert SE: Acute myeloid leukemia associated with $\mathrm{t}(8 ; 21)$ or trisomy 8 in children with neurofibromatosis type 1 . J Pediatr Hematol Oncol 25: 343, 2003

28. Schoch C, Haase D, Fonatsch C, Haferlach T, Löffler H, Schlegelberger B, Hossfeld DK, Becher R, Sauerland MC, Heinecke A, Wörmann B, Büchner T and Hiddemann W: The significance of trisomy 8 in de novo acute myeloid leukaemia: the accompanying chromosome aberrations determine the prognosis. German AML Cooperative Study Group. Br J Haematol 99: 605-611, 1997

29. Lai YY, Qiu JY, Jiang B, Lu XJ, Huang XJ, Zhang Y, Liu YR, Shi HL and Lu DP: Characteristics and prognostic factors of acute myeloid leukemia with $\mathrm{t}(8 ; 21)$ (q22;q22). Zhongguo Shi Yan Xue Ye Xue Za Zhi 13: 733-740,2005

30. Agular A: Translocation $(8 ; 21)(\mathrm{q} 22 ; \mathrm{q} 22)$ without rearrangement of RUNX1 and RUNX1T1 genes in a patient with refractory anemia with excess of blasts. Cancer Genet Cytogenet 180: 85-86, 2008.

31. Gandhi MS, Stringer JR, Nikiforova MN, Medvedovic M and Nikiforov YE: Gene position within chromosome territories correlates with their involvement in distinct rearrangement types in thyroid cancer cells. Genes Chr Cancer 48: 222-228, 2009.

32. Henegariu O, Heerema NA, Lowe Wright L, Bray-Ward P, Ward DC and Vance GH: Improvements in cytogenetic slide preparation: controlled chromosome spreading, chemical aging and gradual denaturing. Cytometry 43: 101-109, 2001.

33. Bhatt S, Moradkhani K, Mrasek K, Puechberty J, Lefort G, Lespinasse J, Sarda P, Liehr T, Hamamah S and Pellestor F: Breakpoint characterization: a new approach for segregation analysis of paracentric inversion in human sperm. Mol Hum Reprod 13: 751-756, 2007

34. Weise A, Heller A, Starke H, Mrasek K, Kuechler A, PoolZobel BL, Claussen U and Liehr T: Multitude multicolor chromosome banding (mMCB) - a comprehensive one-step multicolor FISH banding method. Cytogenet Genome Res 103: 34-39, 2003

35. Liehr T, Heller A, Starke H, Rubtsov N, Trifonov V, Mrasek K, Weise A, Kuechler A and Claussen U: Microdissection based high resolution multicolor banding for all 24 human chromosomes. Int J Mol Med 9: 335-339, 2002.

36. Weise A, Mrasek K, Fickelscher I, Claussen U, Cheung SW, Cai WW, Liehr T and Kosyakova N: Molecular definition of high-resolution multicolor banding probes: first within the human DNA sequence anchored FISH banding probe set. J Histochem Cytochem 56: 487-493, 2008.

37. Hunstig F, Manvelyan M, Bhatt S, Steinhaeuser U and Liehr T: Three-dimensional interphase analysis enabled by suspension FISH. In Fluorescence In Situ Hybridization (FISH) Application Guide. Liehr T (ed.) Springer-Verlag, Berlin, pp313-222, 2009.

38. Paulsson K, Fioretos T, Strömbeck B, Mauritzson N, Tanke HJ and Johansson B: Trisomy 8 as the sole chromosomal aberration in myelocytic malignancies: a multicolor and locus-specific fluorescence in situ hybridization study. Cancer Genet Cytogenet 140: 66-69, 2003.

39. Karst C, Gross M, Haase D, Wedding U, Höffken K and Liehr T, Mkrtchyan H: Novel cryptic chromosomal rearrangements detected in acute lymphoblastic leukemia detected by application of new multicolor fluorescent in situ hybridization approaches. Int J Oncol 28: 891-897, 2006

40. Gross M, Mkrtchyan H, Glaser M, Fricke HJ, Höffken K, Heller A, Weise A and Liehr T: Delineation of yet unknown cryptic subtelomere aberrations in 50\% of acute myeloid leukemia with normal GTG-banding karyotype. Int J Oncol 34: 417-423, 2009. 